\title{
NASR ABDRABO
}

The Defense Language Institute Foreign Language Center (DLIFLC), United States

\section{SEMANTIC ENCODING STRATEGY TRAINING IN FOREIGN LANGUAGE ACQUISITION: THE MODERN STANDARD ARABIC (MSA) MODEL}

\begin{abstract}
:
This presentation represents a paper devoted to pedagogical participation in researches conducted in applied linguistics literature, seeking to take an active role in maximizing the effectiveness of foreign language (FL) teaching and learning strategies. The paper highlights an innovative foreign language teaching strategy, that is, applying 'semantic-encoding strategy training' in foreign language acquisition, giving weight to Modern Standard Arabic (MSA) teaching and learning strategies. Three research questions guided the paper topic:

$\mathrm{RQ1}$ : How can foreign language learners acquire new input effectively?

RQ2: What Brodmann's cortical areas are involved in semantic encoding processing during intentional encoding?

RQ3: How can MSA instructors conduct semantic encoding strategy training effectively in classroom?
\end{abstract}

The researcher initiated the paper by reminding of 'information processing' in human brain to indicate the role of 'semantic encoding' in foreign language acquisition.

The paper referred to two experiments conducted by two teams of practitioners composed of psychologists, radiologists and psychiatrists, who were interested in investigating the role and function of Brodmann's cortical areas assigned to language learning:

1. Demb et al: Semantic encoding and retrieval in the left inferior prefrontal cortex (LIPC): A functional MRI study of task difficulty and process specificity.

2. Kirchhoff et al: Cognitive and neural effects of semantic encoding strategy training in older adults. The researcher demonstrated Brodmann's cortical areas involved in semantic encoding processing during intentional encoding, as well as the particular function of each area during language learning:

- $\square$ Area 45- Pars Traingularis (Broca's area),

- $\square$ Area 46- Dorsolateral Prefrontal Cortex,

- $\square$ Area 47 - Inferior Prefrontal Gyrus,

- $\square$ Medial superior fontal gyrus (Areas $8,9 \& 10$ ),

- $\square$ Right prefrontal gyrus (Area 4),

- $\square$ Left caudate (Area 22),

- $\square$ Prefrontal lateral temporal (includes areas $9 \& 46$ ), and

- $\square$ Left lateral temporal (Area 21).

The researcher introduced 'Systematically- Linguistic Structured Pattern' (SLSP) as "a systematic-linguistic pattern facilitates perceiving the linguistic concept of the interlocking and intertwined grammatical components and linguistic characteristics of a language taught as a target language (TL) and serves as semantic encoding-based-teaching approach.".

The researcher concluded the paper by providing a model of 'semantic encoding strategy training' application employing SLSP in MSA instruction, which can be implemented in MSA learning setting, 
aiming at reducingleliminating the challenges that learners encounter during MSA acquisition.

\section{Keywords:}

information processing; semantic encoding; fMRI; Brodmann's cortical areas 45, 46, 47, 8, 9\&10, 4, 22, 9\&46, and 21; semantic encoding strategy training; Arabic language linguistic characteristics; semantic encoding-based-MSA teaching approach; systematically-linguistic structured pattern (SLSP); Sandhi.

JEL Classification: A19 


\section{RQ1: What supports foreign language learners acquiring new input effectively?}

\section{Semantic Encoding}

Encoding is the process of getting information into memory for storage. Semantic encoding is a specific type of encoding, during which the meaning of something (a word, phrase, picture, event, whatever) is encoded as opposed to its sound or vision (Tulving, 1983). Research suggests that we have better memory for things we associate meaning to and store using 'semantic encoding' (Demb et al. 1995).

\section{Information processing}

Information processing includes three main stages: acquiring, retaining, and using.

2. Acquiring Stage: During this stage, learners receive new information $\backslash$ knowledge from the external environment. The new input moves to learner's 'sensory generators', and then to their short-term memory STM (figure 1).

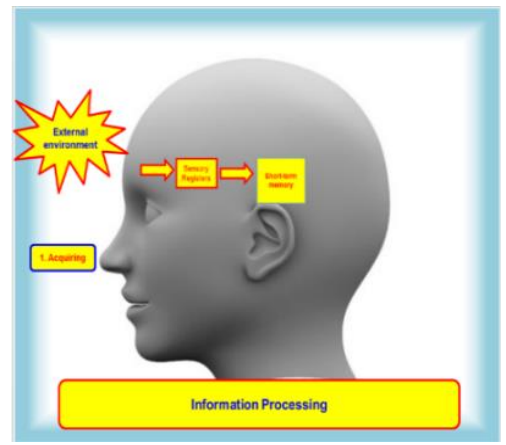

Figure (1)

If the new input is not stored semantically (deeply) in the learner's STM, it moves to the learner's waste memory area where it might vanish and lost (figure 2).

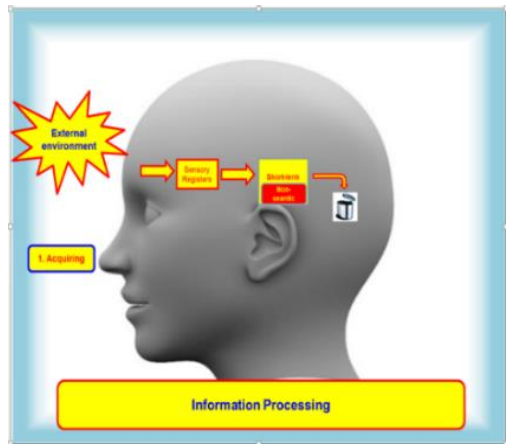

Figure (2)

If the new input stored semantically in STM, it will convert to 'recognizable patterns' (figure 3), and STM will turn to 'working memory' WM. Then, the new recognizable-patterned input will move to the learner's 'long-term memory' LTM where it will remain there subject to 'activation' by a stimulus (figure 4). 


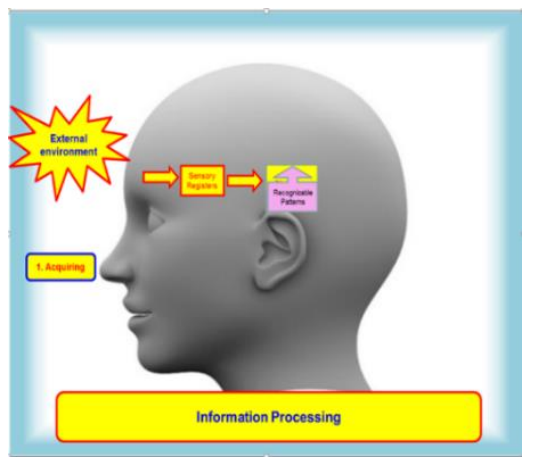

Figure (3)

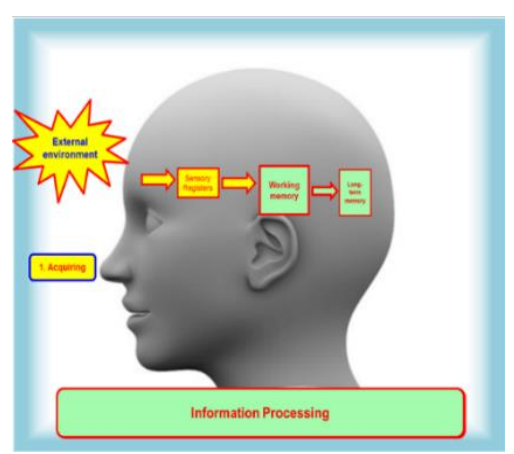

Figure (4)

2. Retaining Stage: When a learner needs to retrieve the information/knowledge stored in their LTM, the retrieval process occurs when stimuli offered to learners as brain storming activity (pre-listening, pre-reading, questions andlor discussion). The provided stimulus would activate the information lknowledge stored in learners' LTM, enabling them to link the knowledge activated in their LTM to the ongoing learning topic (figure 5).

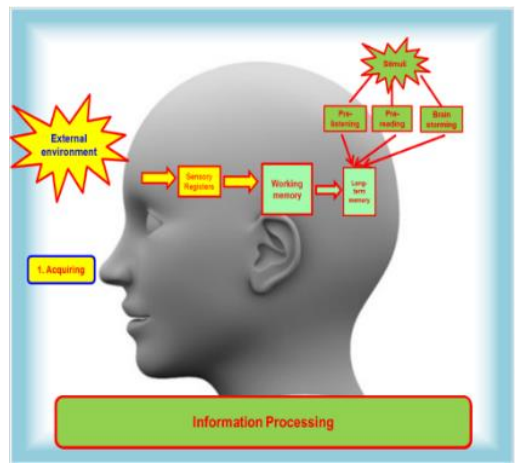

Figure (5)

3. Using Stage: During this stage, the reactivated information $\mid k n o w l e d g e$ converts LTM to working memory WM. This reactivated infolknowledge moves to the learners 'response generator' where the learner becomes capable of responding to the learning situation by remembering andlor answering (figure 6). 


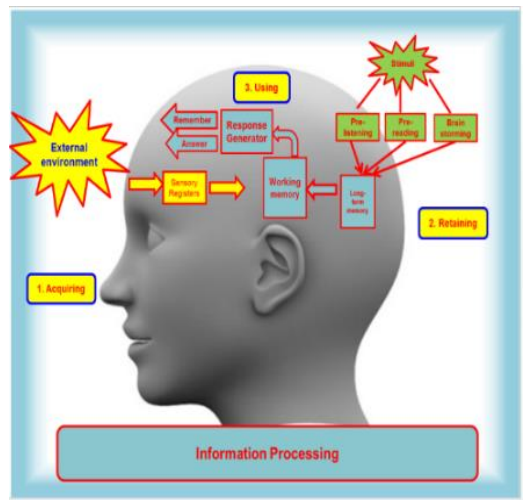

Figure (6)

RQ2: What Brodmann's cortical areas are involved in semantic encoding processing during intentional encoding?

Two teams of practitioners composed of psychologists, radiologists and psychiatrists 'Demb et al' \& 'Kirchhoff et al' - sought to investigate the function of human brain areas (Brodmann's Cortical Areas) during language learning as well as the role of each area in foreign language acquisition.

Each team conducted an experimental study, experimenting different areas of Brodmann's cortical areas -- using functional magnetic resonance imaging fMRI -- to determine what areas of the human brain would become active during the process of foreign language learning; or rather, what Brodmann's cortical areas are assigned to facilitating a student's learning of a foreign language.

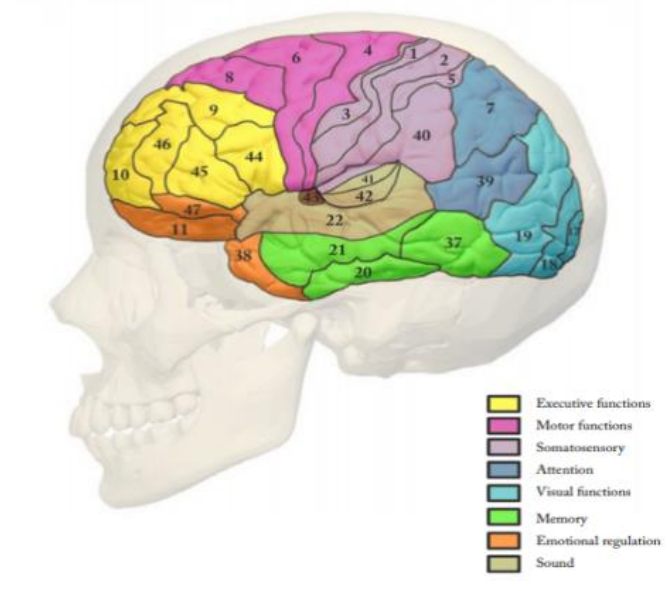

Brodmann's Cortical Areas

Trans Cranial Technologies (2012)

1. Demb et al's study 'Semantic encoding and retrieval in the left inferior prefrontal cortex (LIPC): A functional MRI study of task difficulty and process specificity' was conducted based on the argument that "the prefrontal cortex (PFC) is the brain region that 
has been implicated in planning complex cognitive behavior, personality expression, decision making, and moderating social behavior" (Demb et al, 1995). According to Dahlitz (2017), "the basic activity of this brain region [PFC] is orchestration of thoughts and actions in accordance with internal goals". Scientists argue that words are typically better remembered when encoded for meaning (semantic or "deep" encoding) rather than for appearance (nonsemantic or "shallow" encoding) (Craik and Lockhart, 1972; Gabrieli et al (1995), In Demb et al, 1995).

Experimental studies using 'functional magnetic resonance imaging' (fMRI) and 'positron emission tomography' (PET) - an imaging test that helps reveal how human tissues and organs are functioning - indicated left inferior prefrontal cortex LIPC involvement in semantic encoding (Demb et al, 1995).

Study and conclusion: Demb et al examined LIPC, that is, 'Brodmann's areas 45, 46, 47'. Hereunder the associated functions of these three areas in language and memory functions (Trans Cranial Technologies, 2012).

- Area 45- Pars Traingularis (Broca's area)

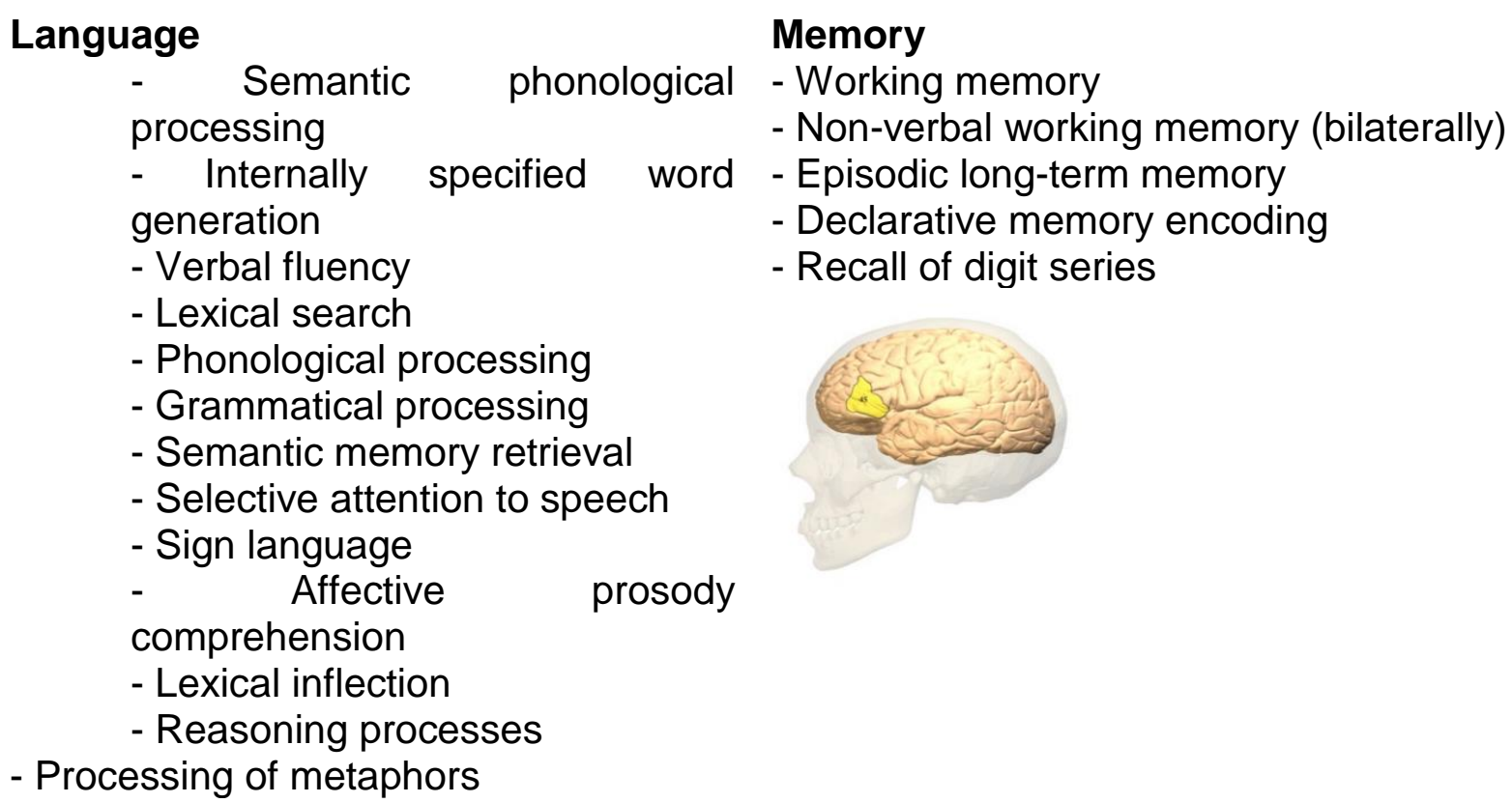

- Area 46- Dorsolateral Prefrontal Cortex
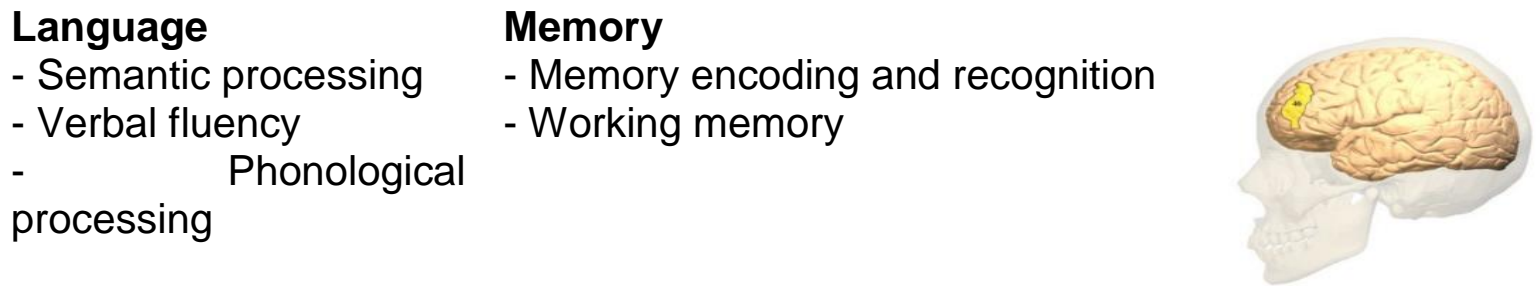


\section{- Area 47 - Inferior Prefrontal Gyrus}

\section{Language}

- Semantic processing

- Semantic encoding

- Active semantic retrieval

- Phonological processing

- Single word reading

- Lexical inflection

- Affective prosody

- Selective attention to speech
Memory

- Working memory

- Episodic long-term memory

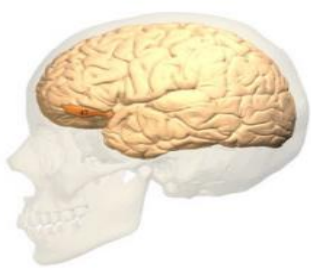

During the fMRI scanning, Demb et al noticed that when Brodmann's areas 45, 46 and 47 were activated during semantic encoding relative to nonsemantic encoding - regardless of the relative difficulty of the nonsemantic encoding task - they showed notable, considerable increase of activation. Accordingly, the study concluded that LIPC activation appears to be related to semantic encoding and not task difficulty (Demb et al, 1995, p. 570)

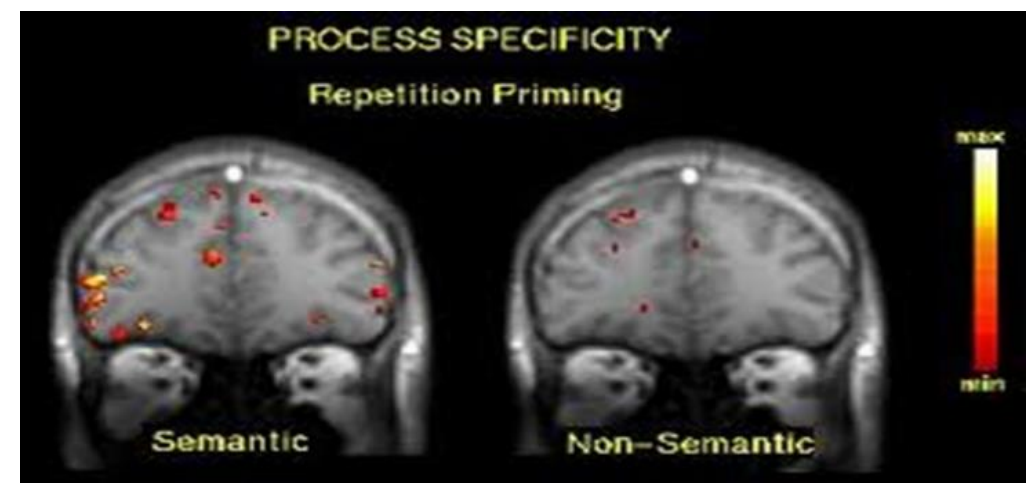

\section{Semantic vs. Nonsemantic encoding}

Demb et al (1995)

\section{Kirchhoff et al's study, 'Cognitive and neural effects of semantic encoding strategy} training in older adults', was grounded on prior research argument that older adults are less likely, than young adults, to use effective learning strategies during intentional encoding.

Kirchhoff et al conducted fMRI test to investigate whether training older adults to use semantic encoding strategies can improve their self-initiated use of those strategies as well as their recognition memory. The $\mathrm{fMRI}$ scanning examined the 'medial superior fontal gyrus' (Brodmann's areas 8, 9, 10); 'right prefrontal gyrus' (Brodmann area 4); 'left caudate' (Brodmann area 22); 'prefrontal lateral temporal' (Brodmann areas 9 \& 46); and 'left lateral temporal' (Brodmann's area 21). 
Trans Cranial Technologies (2012) underlie the cortical functions of these Brodmann's cortical areas associated to the purpose of this paper as follows:

- Medial superior fontal gyrus (Areas 8, 9\&10)

Area 8 - Includes Frontal Eye Fields participates in different executive functions including those associated with language learning (language and 'memory).

Language

- Speech motor programming

- Language processing (STM)

- Language translation

- Generating sentences

- Lipreading (STM)
Memory

- Working memory (WM)

- Perceptual priming

- Memory retrieval

- Topographic memory

Areas 9\&10 - Dorsolateral / Anterior Prefrontal Cortex participate in different executive functions including those associated with language learning (language and memory).

$\begin{array}{ll}\text { Language } & \text { Memory } \\ \text { - Syntactic processing } & \text { - Working memory } \\ \text { - Metaphor } & \text { - Spatial memory } \\ \text { comprehension } & \text { - Short-term memory } \\ \text { - Verbal fluency } & - \text { Memory encoding and } \\ \text { - Semantic categorization } & \text { recognition } \\ \text { - Word-stem completion } & \text { - Memory retrieval } \\ \text { - Generating sentences } & \text { - Recency judgement } \\ \text { - Verb generation } & -\quad \text { Event-and time-based } \\ & \text { prospective memory } \\ & \text { - Prospective memory (Lateral) } \\ & \text { - Intentional forgetting }\end{array}$

- Right prefrontal gyrus (Area 4)

Area 4-Primary Motor Cortex participates in different executive functions associated with language learning.

\section{Functions}

- Verbal encoding during a non-semantic process

- Attention to action (posterior)

- Topographic memory (motor memory) for visual landmarks

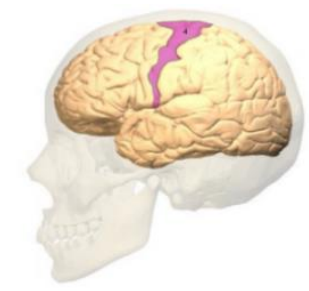


- Left caudate (Area 22)

Area 22 - Superior Temporal Gyrus (part of Vernicks's area) participates in different executive functions including those associated with language learning (language and language-related).

Language

- Receptive language

- Auditory language processing

- Semantic processing

- Frequency deviant detection

- Internally-specified word generation
Language-related

- Selective attention to

speech

- Affective prosody

comprehension

- Learning a tone-based

second

language

- Repeating words

- Prefrontal lateral temporal (includes areas $9 \& 46$ mentioned above)

- Left lateral temporal (Area 21)

Area 21 - Middle Temporal Gyrus participates in different executive functions including those associated with language learning (language)

\section{Language}

- Selecting processing of text and speech

- Semantic processing

- Prosodic integration

- Sentence generation

- Word generation

After data collection and analysis, Kirchhoff et al reported that conducting semantic encoding strategy training during intentional encoding increase older adults' brain activity in the medial superior frontal gyrus (areas 8, 9\&10); right precentral gyrus (area 4); left caudate (area 22); prefrontal lateral temporal (areas 9 \& 46); and left lateral temporal (area 21).

Kirchhoff et al contend that "these neuroimaging results demonstrate that semantic encoding strategy training can alter older adults' brain activity patterns during intentional encoding and [argue] that young and older adults may use the same network of brain regions to support self-initiated use of verbal encoding strategies" (Kirchhoff et al, 2011, p.788) 
RQ3: How can MSA instructors conduct semantic encoding strategy training effectively in classroom?

Educators argue that 'semantic encoding strategy training' significantly increase older adults' mean brain activity during intentional encoding (Kirchhoff et al, 2011; Cabeza, 2002; Rajah \& Esposito, 2005; Reuter-Lorenz \& Lusting, 2005; Persson \& Nyberg, 2005; and Spreng et al, 2010).

"Arabic is truly a unique language characterized by [unparalleled] linguistic characteristics that cannot be [commonly] found in other languages" (Abdrabo, 2018). This language characterized by distinct grammatical and linguistic characteristics, which Modern Standard Arabic (MSA) instructors and curriculum developers can employ in creating innovative, significant and applicable teaching and learning strategies, which can be embedded in learning material and curricula as well. These strategies could be a practical application of 'semantic encoding strategy training' that could be provided to MSA students, aiming at reducingleliminating the learning challenges they encounter during language learning.

The researcher - MSA educator -- conducted some grammatical and linguistic analyses to some characteristics of the Arabic language, and managed to systemize some grammatical components and linguistic characteristics in a systematic pattern. This pattern aims at facilitating the process of perceiving the linguistic concept of the interlocking and intertwined grammatical components and linguistic characteristics of Arabic taught as a target language (TL), that is, 'Systematically-Linguistic Structured Pattern' (SLSP).

\section{Systematically- linguistic structured pattern (SLSP)}

Systematically-linguistic structured pattern (SLSP) is "a systematic-linguistic pattern facilitates perceiving the linguistic concept of the interlocking and intertwined grammatical components and linguistic characteristics of a language taught as a target language (TL) and serves as semantic encoding-based-teaching approach.".

SLSP: Semantic encoding strategy-based-teaching approach in MSA classroom Semantic vs. Non-semantic MSA Teaching Strategy

\section{Transitive vs. Intransitive Verbs}

\begin{tabular}{|l|r|}
\hline Non-semantic teaching approach \\
\hline 1. John came early today. & حضر جون اجتماعًا هامًا اليوم. البوم. \\
\hline $\begin{array}{l}\text { 2. John attended an important meeting } \\
\text { today. }\end{array}$ \\
\hline
\end{tabular}

The above two sentences include the Arabic verb ' meanings (came or attended), causing confusion to a student during reading or listening. A teacher may translate this verb as 'came' in the first sentence, and 'attended' in the second sentence. 
To eliminate learners' confusion, Arabic instructors -- adopting 'semantic encoding-basedteaching approach' -- may consider the following:

\section{Semantic encoding-based-teaching approach}

\begin{tabular}{|c|c|}
\hline to come = (intransitive verb) حضر & حضر جون مبكرًا اليوم. \\
\hline to attend = حضر (transitive verb) & حضر جون اجتماعًا هامًا اليوم. \\
\hline
\end{tabular}

2. Verb Tense-based- Different Meaning (emphatic vs. non-emphatic)

Non-semantic teaching approach

1. The teacher came today\The teacher did come) قلق حضر الأستاذ اليوم. today

2. The teacher maylmight come today.

Conducing grammatical analysis to the above two sentences highlights that these two sentences included verb "حَضَرَ" as intransitive verb meaning, "to come". This verb (in the first sentence) was conjugated in the past tense as " حَضَرَر "preceded by the indefinite or definite meaningless emphasis particle "قل / expressing emphatic 'coming' as 'did come'. However, this verb was conjugated (in the second sentence) in the present tense as "يحضر" preceded by the indefinite meaningless particle "قُ" expressing non-emphatic 'coming' as 'may\might come'.

Teachers adopting 'semantic encoding-based-teaching approach' may draw students' attention to the following grammatical rule:

Semantic encoding-based-teaching approach

\begin{tabular}{|c|c|}
\hline emphatic verb = (past tense) & لقِ / قِ حضر الأستاذ اليوم. \\
\hline ق قلـ + & قآَّ يحضاذ قد الأستاذ اليوم. \\
\hline
\end{tabular}

3. The Arabic Equivalent Verb vs. English Prefix "Re..."

(Noun vs. Verbal noun)

\begin{tabular}{|c|c|}
\hline Jon-semantic teaching approach & \\
\hline 1. The police returned the stolen car. & أعادت الثرطة السيارة المسروقة. \\
\hline 2. The police reconsidered the situation. & أعادت الشرطة تقييم الموقف. \\
\hline
\end{tabular}

The above two sentences included the Arabic verb 'أعاد', translated 'returned' as a transitive verb in the first sentence, and as 'reconsidered' in the second sentence. Translation lacking emphasis on grammatical rules seems 'non-semantic' rather than 'semantic'.

To eliminate learners' confusion, Arabic instructors may consider the following: 
Verb 'أعاد' in general is a transitive verb that requires an object. If the object is 'a noun' such as 'السيارة المسروقة' 'meaning 'the stolen car' in the first sentence, in this case, the verb means 'returned'. While if the object is 'a verbal noun' such as 'تقييم' in the second sentence meaning 'considering', in this case, the same verb 'أعاد' is not viewed as a verb, but it functions as the English prefix 're-......' with an overall meaning as 'reconsidered' as shown in this table.

\begin{tabular}{|c|c|}
\hline \multicolumn{2}{|c|}{ Semantic encoding-based-teaching approach } \\
\hline to returnlget something $=$ (noun) $\begin{array}{c}+ \text { أعاد } \\
\text { back }\end{array}$ & أعادت الشرطة السيارة المسروقة. \\
\hline 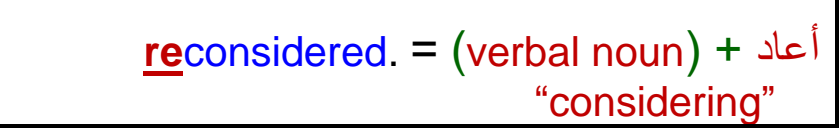 & قيبيم الموقف. \\
\hline
\end{tabular}

\section{Formal Passive Voice (formal reporting)}

"News, Regulations, Instructions, Announcements, Ads...etc."

\begin{tabular}{|l|l|}
\hline Non-semantic teaching approach \\
\hline The terrorists have been arrested today. \\
Application are accepted within two \\
weeks.
\end{tabular}

MSA learners are familiar with the traditional structure of the passive voice case as long as the verb is there, characterized by the traditional diacritics marking the verb as in '

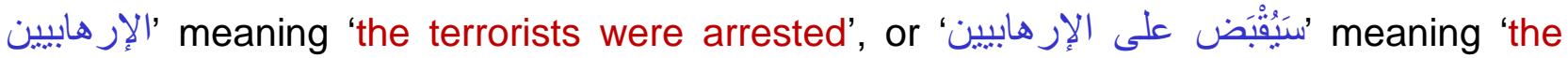
terrorists will be arrested'.

Modern Standard Arabic (MSA), used in writing or reporting "news, regulations, instructions, announcements and ads...etc." formally, tends to give emphasis on the action or event, other than to the actor(s). This approach introduces the passive voice formally, using a unique formula composed of two parts: the Arabic verb '“تَّ" conjugated in the tense of the target action such as "ن" in the past; "نتخ" in the present and "نينم" in the future (meaning, 'happened', 'happens' and 'will happen' proceeded by the verbal noun of the action verb. This unfamiliar formula, most likely, confuses learners who usually accustomed to recognizing the passive voice either through diacritics (in reading), or the speaker's 'vocal output' (in listening). 
To eliminate learners' confusion, Arabic instructors, when introducing the formal passive voice, may consider the following table:

\section{Semantic encoding-based-teaching approach}

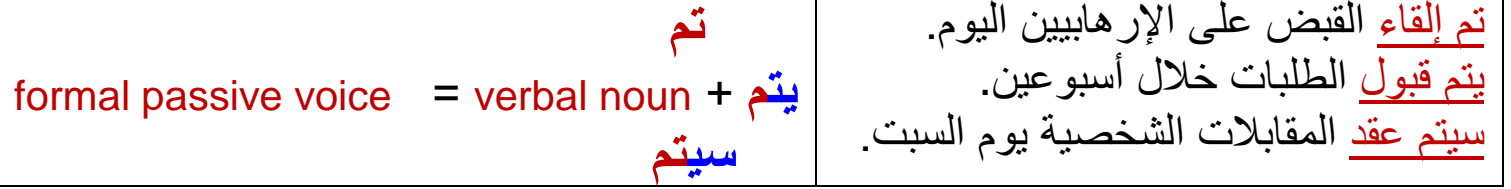

\section{Actor Category-based- Multi-meaning Arabic Verb}

\begin{tabular}{|c|c|}
\hline Non-semantic teaching approach & \\
\hline $\begin{array}{l}\text { 1. California State is located on the west } \\
\text { coast. }\end{array}$ & تقع و لاية كاليفورنيا على الساحل الغربي. \\
\hline $\begin{array}{l}\text { 2. My home is located behind the train } \\
\text { station. }\end{array}$ & خلف محطة القطار \\
\hline 3. These incidents take place in NY city. & تقع هذه الأحداث في مدينة نيويورك. \\
\hline 4. A traffic accident took place on HW 101. & وقع حادث مروري على الطريق السريع 1 ـ1. \\
\hline 5. The child fell down to the floor. & وقع الطفل على الأرَض. \\
\hline 6. The car fell down in a cliff. & وقعت السيارة في جُرف \\
\hline
\end{tabular}

Conducting grammatical analysis to the above six sentences, shows that these sentences included the multi-meaning Arabic verb "وقع" conjugated either in the 'present' or 'past' tense, and conducted by 'different actor categories' as follows:

- Sentences (1) \& (2) included verb "وقع", conjugated in the present tense, referred to a specific subject; either a place (California State) or a building (my home). In this case, this verb means "located".

- However, we notice the same verb "وقع" conjugated in the 'present tense' in sentence (3). We also notice that the subject is an 'incident'. In this case verb "وقع" when conjugated in the present tense --means "take placeloccur" particularly in "story telling'.

- In sentence (4) verb, "وقع", conjugated in the 'past tense', refereed to an incident (traffic accident). In this case the verb means "took placeloccurred". MSA learners often find this formula in 'news bulletin' or 'formal reports'.

- In sentences (5) and (6) verb", conjugated in the 'past tense', referred to either a human being (the child) or an inanimate object (the car). In this case verb "وقع" means "fell down or descended". 
Arabic instructors may be interested in the following table:

\begin{tabular}{|c|c|}
\hline \multicolumn{2}{|l|}{ emantic encoding-based-teaching approach } \\
\hline \multirow[b]{2}{*}{ 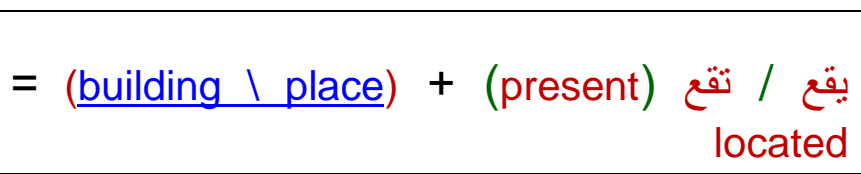 } & تقع و لاية كاليفورنيا على الساحل الغربي. \\
\hline & يقع بيتي خلف محطة القطار. \\
\hline \multirow{2}{*}{ 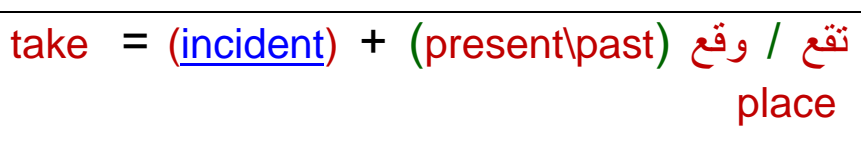 } & تقع هذه الأحداث في مدينة نيويورك. \\
\hline & وقع حادث مروري على الطريق السريع 1 · . \\
\hline \multirow{2}{*}{ fall $=$ (personlobject) $+\underset{\text { downldescend }}{\text { (past) }}$} & وقع الطفل على الأرض. \\
\hline & وقعت السيارة في جُرف. \\
\hline
\end{tabular}

\section{The multiple function \& meaning of the Arabic letter "Fa'a ...ف" (As a prefix)}

\begin{tabular}{|c|c|}
\hline c teachil & \\
\hline $\begin{array}{l}\text { People differ in their favorite foods. For } \\
\text { instance, some people prefer beef and } \\
\text { others prefer seafood. Yesterday, my } \\
\text { friend John and I were hungry, and } \\
\text { accordingly we went to a restaurant for } \\
\text { dinner. John ordered grilled meat, as for } \\
\text { me }{ }_{2} \text { I ordered fried fish. After dinner, we } \\
\text { drank lemon juice followed by American }\end{array}$ & 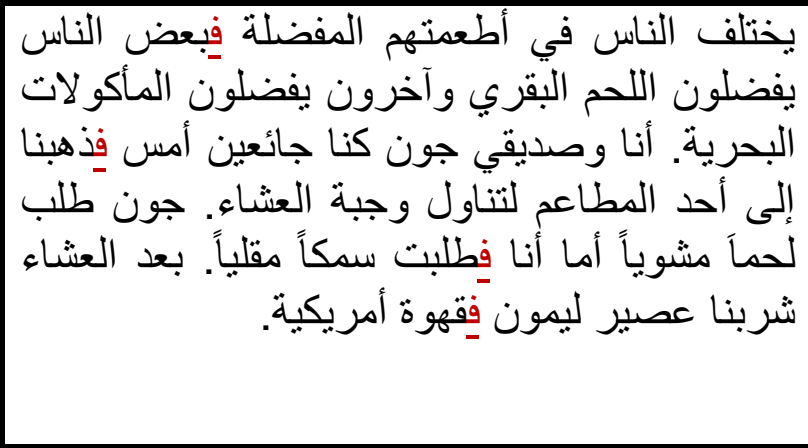 \\
\hline
\end{tabular}

When teaching this text, students might be confused about the meaning of the repetitive

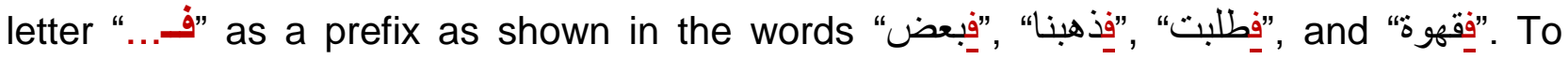
eliminate students' confusion, instructors may break up the above text to four couples of compound sentences (each couple composed of two simple sentences joined by the letter "...." as a prefix), highlighting the relationship between each couple of the simple sentences, as well as the function of the prefix "....

\section{a. Explanatory “..... الفاء التوضيحية "meaning: “for instance”}

\section{Non-semantic teaching approach}

People differ in their favorite foods. For instance, some people prefer beef and others prefer seafood.

$$
\begin{aligned}
& \text { يختلف الناس في أطعثنه المفضلة فبعض الناس } \\
& \text { يفضلون اللحم البقري وآخرون يفضلون المأكو لات }
\end{aligned}
$$

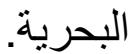

This compound sentence is composed of two simple sentences: the first sentence "People differ in their favorite foods" introduces a general idea, reality or a phenomenon that everybody knows well, while the second sentence, "some people prefer beef and others prefer seafood" attached to the prefix letter "... ف.", clarifies the differences between peoples' 
preferences. The prefix "....ف" in this case called "Explanatory.... " known in Arabic as " الفاء " which function is providing detailed information or example(s) that clarify the general idea of the first sentence. "Explanatory...." means "for instance" or "for example" as shown in this table:

\begin{tabular}{|c|c|c|}
\hline Semantic encoding-based-teaching approa & & \\
\hline $\begin{array}{l}\text { The embodiment of the general } \\
\text { idealphenomenon } \\
\text { المضكو لات البحرية. يفضلون اللحم البقري وآخرون يفضلون } \\
\text { Some people prefer beef and others prefer } \\
\text { seafood. }\end{array}$ & $\begin{array}{l}\Leftrightarrow \\
\text { For } \\
\text { instance, }\end{array}$ & $\begin{array}{l}\text { General idea \Phenomenon } \\
\text { يختلف الناس في أطعمنهم المفضلة } \\
\text { People differ in their favorite } \\
\text { foods }\end{array}$ \\
\hline
\end{tabular}

b. $\quad$ Causal “.... فاء السبية " meaning: "accordingly”

\begin{tabular}{|c|c|}
\hline h & \\
\hline $\begin{array}{l}\text { Yesterday, my friend John and I were } \\
\text { hungry, and accordingly we went to a } \\
\text { restaurant for dinner. }\end{array}$ & 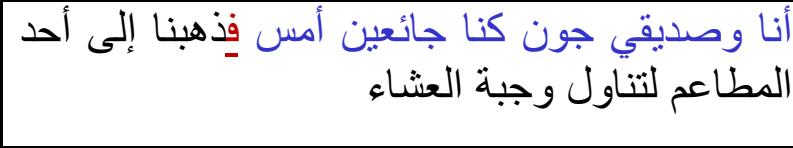 \\
\hline
\end{tabular}

This compound sentence is composed of two simple sentences: the first "Yesterday, my friend John and I were hungry" is the reasonlcauselmotive for the second one "we went to a restaurant for dinner" representing the result/response to the first sentence. In this case the prefix letter ".... فاء" joining 'reason' and 'result' called "Causal...." known in Arabic as " السبيية", which means "accordingly' as shown in this table.

\begin{tabular}{|c|c|c|}
\hline \multicolumn{3}{|c|}{ Semantic encoding-based-teaching approach } \\
\hline $\begin{aligned} & \text { Result \Response } \\
& \text { ذهبنا إلى أحد المطاعم لتناول وجبة العثاء }\end{aligned}$ & $\rightarrow$ & $\begin{array}{r}\text { Reason \Motive } \\
\text { أناوصديقي جون كنا جائعين أمس }\end{array}$ \\
\hline we went to a restaurant for dinner & accordingly & $\begin{array}{l}\text { Yesterday, my friend John and I } \\
\text { were hungry }\end{array}$ \\
\hline
\end{tabular}

\section{C. الفاء الاستئنافية ” ف... Resumption “ Resented by: “,” in English}

\begin{tabular}{|l|}
\hline Non-semantic teaching approach \\
\hline $\begin{array}{l}\text { John ordered grilled meet, as for me } \\
\text { ordered fried fish }\end{array}$ \\
\hline
\end{tabular}

This compound sentence is composed of two simple sentences: the first sentence is "John ordered grilled meet" and the second one is "I ordered fried fish". The two sentences were joined by "أمّ" meaning "as for' followed by the subject of the second sentence "me". From the grammatical view, the first sentence considered a "dependent clause" which requires an "independent clause" that would complete the meaning of the compound sentence to 
become "meaningful sentence". According to the English grammatical rule, a comma "," is required after an 'independent clause' to be followed by a 'dependent clause'.

In our case, a "Resumption.... الفاء الاستئنافية "was attached to the verb of the second sentence "طلب" meaning "ordered” ending by the Arabic suffix “" so that the overall meaning becomes "فطلبث" meaning ", I ordered". As such, "Resumption....ف" despite being meaningless, it represents and functions as the comma "," in an English sentence that would connect a "dependent clause" to an "independent clause". The "Resumption...." is known in Arabic grammar as "الفاء الاستنئافية" as shown in the following table.

\begin{tabular}{|c|c|c|}
\hline \multicolumn{3}{|c|}{ Semantic encoding-based-teaching approach } \\
\hline طلبثُ سمكاً مقلياً & $\dot{\theta}$ & جون طلبَ لحماً مشوياً أما أنا (as for me) \\
\hline Dependent Clause & 9 & Independent Clause \\
\hline
\end{tabular}

d. Coordinating conjunction "...ف فاء العطف meaning: "followed by"

\begin{tabular}{l}
\hline Non-semantic teaching approach \\
$\begin{array}{l}\text { After dinner, we drank lemon juice } \\
\text { followed by American coffee. }\end{array}$
\end{tabular}

This compound sentence was originally composed of two simple sentences: "After dinner, we drank lemon juice" and then, "We drank American coffee". These two sentences include the same subject "we" who did the same actionlverb "drank". In English, we join simple sentences, sharing same subject and verblaction, by using a conjunction after deleting the repetitive subject (actor) in the second sentence. Like English, in this case, we used "coordinating conjunction.... meaning "followed by" or "and then". It is known in Arabic grammar as "فاء العطف" as shown in this table.

\begin{tabular}{|c|c|c|}
\hline \multicolumn{3}{|c|}{ Semantic encoding-based-teaching approach } \\
\hline قهوة أمريكية & ف & بعد العشاء شربنا عصير ليمون \\
\hline $\begin{array}{l}\text { The same subject (we) conducted the } \\
\text { same action (drank) to another object } \\
\text { (American coffee) }\end{array}$ & $\begin{array}{l}\text { followed by } \\
\text { (and then) }\end{array}$ & $\begin{array}{l}\text { Subject (we) conducted an } \\
\text { action (drank) to an abject } \\
\text { (lemon juice) }\end{array}$ \\
\hline
\end{tabular}

\section{The Role of SLSP in Listening Comprehension}

Educators define listening process as "the ability to identify and understand what others are saying. This involves understanding a speaker's accent or pronunciation, his grammar and his vocabulary, and [then] grasping his meaning" (Howatt \& Dakin, 1974). Others define it as "an important skill through which language learners internalize linguistic information without which they cannot produce language" (Brown, 2001). According to 
Wolvin \& Coakley (1988), listening comprehension is "making sense of oral input by attending to the message", and is "a process entailing hearing, attending to it, understanding, evaluating, and responding to spoken messages" (Floyed et al., 1985).

According to Dejean de la Bàtie (1993), beginning language learners have a difficult task listening due to their limit exposure to connected speech, inadequate phonological competence, and inefficient processing strategies.

One crucial challenge facing MSA learners during listening comprehension (LC) is 'Sandhi' (Abdrabo, 2016) defined by Henrichsen as "the phonological modification of grammatical forms which have been juxtaposed". Sandhi has five forms: 'assimilation'; 'mutation'; 'contraction'; 'liaison'; and 'elision', and causes a problem to L2 listeners when dividing the stream of speech" (Henrichsen, 1984, p. 311).

\section{SLSP Application in Listening Comprehension}

(Distinguishing between words with similar sounds)

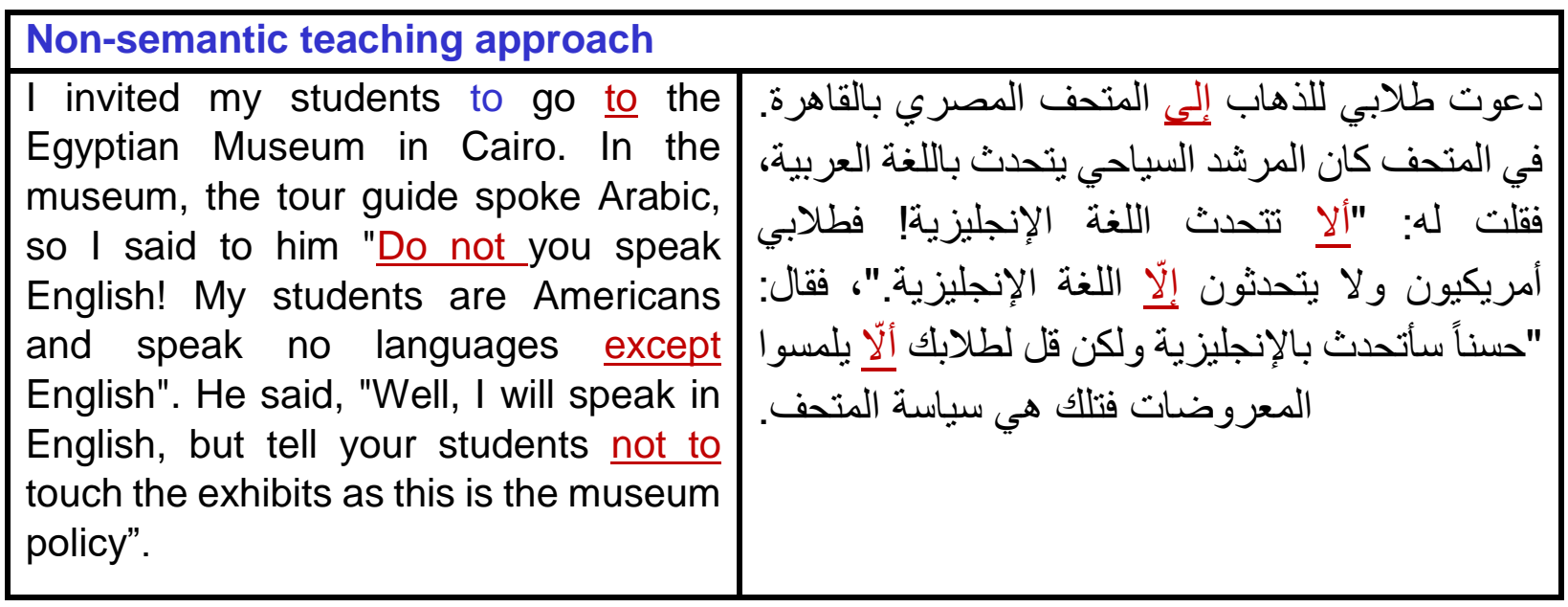

The above passage included four Arabic words: ألّا \إلّا \ألا \إ إلى , which are very close in their vocal outputs, and highly expected to cause confusion to MSA listeners, who will find it hard to determine their meanings, resulting in their misunderstanding of the overall meaning of the passage. MSA instructors can eliminate listeners' confusion and frustration when applying SLSP as a 'semantic encoding-based-teaching approach' through drawing their students' attention to the following MSA grammatical rules:

\begin{tabular}{|l|}
\hline Semantic encoding-based-teaching approach \\
\hline I invited my students to go to the \\
Egyptian Museum in Cairo.
\end{tabular}

1. This Arabic sentence included the word "إلى" which can be determined as a 'locomotive preposition' (equivalent to the English proposition "to" precede to a place). "إلى" can be recognized as an 'locomotive proposition' since it was preceded by the verbal noun "الذهاب" meaning "going" and followed by a place "the Egyptian Museum in Cairo". 


\section{Semantic encoding-based-teaching approach}

"Don't you speak English!"

"ألا تتحدث اللغة الإنجليزية!!

2. This sentence included the word "Yl" as a combination of the non-stressed "Hamza l" and " "l" (as a negation particle). When "precedes the present tense, together they mean: "Don'tlDoesn't (the actor) do!" In this case, "لأ functions as an "Exclamation particle". The exclamation can also be recognized from the speaker's tone.

\section{Semantic encoding-based-teaching approach}

My students are Americans and speak no languages except English"

3. This sentence included the word "עّ" which was characterized by a lower Hamza "!" in the genitive case followed by a noun in the accusative case "English". In this case "إ" " means "except".

\section{Semantic encoding-based-teaching approach}

Tell your students not to touch the exhibits

قل لطلابك ألِّالِ يلمسوا المعروضات

4. This sentence included the word "ألّ" which is a combination of two syllables: the particle "أنْ" representing the infinitive "to" in English, and the negation particle "لا" meaning "not". Both assimilated as "أ" with stressed "lam "J"meaning "not to" followed by the present tense "يلمسو" (they touch). In this context, "أليّ" "functions as "prohibiting particle", and the overall meaning is "Tell your students not to touch".

MSA instructors adopting 'semantic encoding-based-teaching approach' would compile the above four remarks in one table, so that they could provide their students a thorough, informative explanation of "إلى", "إلى" "إلّاّ", giving them the opportunity to conduct informative comparison as follows:

\begin{tabular}{|c|c|}
\hline oding-based-teaching a & $\overline{\text { oach }}$ \\
\hline "To" a place = place + إلى & بالقاهرت. طلابي للذهاب إلى الدتحف المصري \\
\hline $\begin{array}{r}\begin{array}{l}\text { used as 'exclamation }=\text { present }+ \text { أل } \\
\text { particle' meaning "don'tldoesn't someone } \\
\text { do!" }\end{array} \\
\end{array}$ & فقلت له: "ألع تتحدث اللغة الإنجليزية!" \\
\hline meaning "except" that noun $=$ noun + ! & 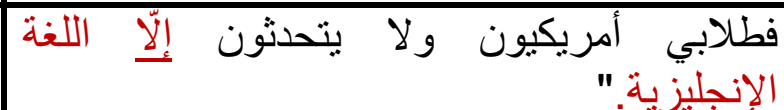 \\
\hline $\begin{array}{r}\text { used as forbidding particle }=\text { present + } \\
\text { assimilated (أن لا) }\end{array}$ & 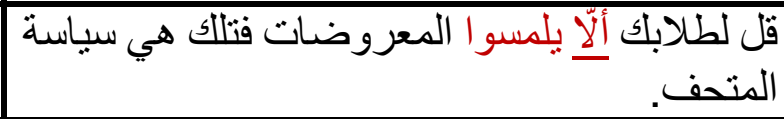 \\
\hline
\end{tabular}




\section{CONCLUSION}

The process of teaching languages as a foreign language (FL), in a formal learning setting, absolutely differs from acquiring a language in an authentic language-acquiring context, where natives use their tongue-language or first language (L1) to satisfy their daily lifeneeds.

Learners, who learn a language in a formal learning setting (classroom), encounter considerable learning challenges. Educators attribute these challenges to many factors, including the major differences between learners' (L1), and the language they strive to learn as a target language ( $\mathrm{TL}$ ) or second language (L2). These are: 'learners' genetic system'; 'language engine' or 'syntactic system'; 'language acquisition'; and 'language resistance' where L2 learners often resist language learning, whether consciously or unconsciously.

Language instructors are invited to have an active role in supporting their students overcome the learning obstacles they encounter and hinder their success in language learning. Adopting innovative teaching approaches and strategies, and providing students with constructive learning strategies and techniques, would undoubtedly have promising impact on producing competent, self-regulated linguists.

This paper tapped on one major challenge facing FL learners in general, and MSA learners in particular, that is 'language engine' or 'syntactic system'. The researcher shed light on 'semantic encoding strategy training' that could be applicable through adopting 'semantic encoding-based-teaching approach' in language learning formal settings.

The researcher introduced 'Systematically-linguistic structured pattern' (SLSP) as "a systematic linguistic pattern facilitates perceiving the linguistic concept of the interlocking and intertwined grammatical components and linguistic characteristics of a language taught as a target language (TL) and serves as semantic encoding-based-teaching approach".

The researcher conducted some Arabic linguistic and grammatical analyses, based on which, he provided "The Modern Standard Arabic (MSA) Model", an applicable model adopting 'semantic encoding strategy training' in MSA learning setting.

The researcher provides this paper hoping it would have its expected impact on maximizing the effectiveness of language teaching and learning strategies, aiming at facilitating perceiving foreign language acquisition -- in general -- and Modern Standard Arabic (MSA) in particular.

Nasr Abdrabo, Ed. D

Associate Professor of Modern Standard Arabic

California-USA 


\section{REFERENCES}

Abdrabo, N. (2018). Globalization of the Arabic language alphabet: influences on contemporary European languages. https://www.researchgate.net/project/Globalization-of-the-Arabic-Alphabet-Influences-onContemporary-European-Languages

Abdrabo, N. (2016). Promoting listening macroskill: the key to mastering L2 acquisition.

https://www.researchgate.net/publication/303752890 Promoting Listening Macroskill The Key to Master ing L2 Acquisition

Abdrabo, N. (2013). Learners' beliefs about the strengths and weaknesses of the modern standard Arabic special assistance program in semester one at the defense language institute foreign language center (DLIFLC).

https://www.researchgate.net/publication/308715067 LEARNERS' BELIEFS ABOUT THE STRENGTHS AND WEAKNESSES OF THE MODERN STANDARD ARABIC SPECIAL ASSISTANCE PRO GRAM IN SEMESTER ONE AT THE DEFENSE LANGUAGE INSTITUTE FOREIGN LANGUA GE CENTER

Brown, H. D. (2001). Teaching by principles: An interactive approach to language pedagogy (2nd ed.). White plains, NY: Pearson Education.

Cabeza, R. (2002). Hemispheric asymmetry reduction in older adults: the HAROLD model. Psychol Aging, 17:85-100.

Craik FIM, \& Lockhart RS (1972). Levels of processing: a framework for memory research 1. Journal of Verbal Learning and Verbal Behavior, 11, 671-684

Dahlitz, M. (2017). Prefrontal cortex. Retrieved 2 June 2018 from: https://www.neuropsychotherapist.com/prefrontal-cortex/

Dejean de la Bâtie, Bernadette. "Word Boundary Ambiguity in Spoken French." Diss., Monash Univ., Melbourne, Australia, 1993.

Demb, J. B., Desmond, J. E., Wagner, A. D., Vaidya, C. J., Glover G. H., \& Gabrieli JDE. (1995). Semantic encoding and retrieval in the left inferior prefrontal cortex: A functional MRI study of task difficulty and process specificity. The Journal of Neuroscience, 15(9): 5870-5878. Department of Psychology and Radiology, Stanford University, Stanford, California 94305-2130.

Floyed, J., Foreswan, S. \& Others (1985). Listening a Practical Approach, Glenview, III, USA.

Gabrieli JDE, Fleischman DA, Keane MM, Reminger SL., Morreil F (1995). Double dissociation between memory systems underlying explicit and implicit memory in the human brain. Psychol Science 6:7682.

Henrichsen, Lynn E. "Sandhi-Variation: A Filter of Input for Learners of ESL." Language Learning 34 (1984): 1003-26.

Howatt, A. \& Dakin, J. (1974). Language laboratory materials, ed. J. P. B. Allen, S. P. B. Allen, and S. P. Corder.

Kirchhoff, B. A., Anderson, B. A., Barch, D. M, \& Jacoby, L. L. (2011). Cognitive and neural effects of semantic encoding strategy training in older adults. Cerebral Cortex April 2012; 788-100.

Logan, J. M., Sanders, A. L., Snyder, A. Z., Morris, J. C., \& Buckner, R. L. (2002). Under- recruitment and nonselective recruitment: dissociable neural mechanisms associated with aging. Neuron, 33:827-840.

Persson, J., Nyberg, L. (2005). Altered brain activity in healthy seniors: what does it mean? Prog Brain Res. 157: 45-56. 
Rajah, M. N., D' Esposito, M. (2005). Region-specific changes in prefrontal function with age: a review of PET and fMRI studies on working and episodic memory. Brain.128: 1961-1083.

Reuter-Lorenz PA \& Lusting C. (2005). Brain aging: recognizing discoveries about the aging mind. Curr Opin Neurobiol. 15:245-251

Reuter-Lorenz, P. A., Jonides, J, Smith, E. E., Hartley, A., Miller, A., Marshuetz, C., \& Koeppe, R. A. (2000). Age differences in the frontal lateralization of verbal and spatial working memory revealed by PET. $J$ Cog Neurosci. 12: 171-187

Rubin, J. (1994). A review of second language listening comprehension research. The Modern Language Journal, 78,199-221.

Salloum, H. (2016). The impact of the Arabic language and culture on English and the other European languages. http://www.alhewar.net/Basket/Habeeb Salloum Spanish Language.htm

Spreng, R. N., Wojtowicz, M, Grady, C. I. (2010). Reliable differences in brain activity between young and old adults: a quantitative meta-analysis across multiple cognitive domains. Neurosci Biobehav Rev. 34:1178-1194.

Trans Cranial Technologies (2012). Cortical Functions Reference. Retrieved 2 June 2018 from: https://www.trans-cranial.com/local/manuals/cortical functions ref v1 0 pdf.pdf

Tulving, E. (1983). Elements of episodic memory. Oxford University Press, Oxford. Cortical Functions Reference. (2012). Retrieved 2 June 2018 from: https://www.transcranial.com/local/manuals/cortical functions ref v1 0 pdf.pdf

Verity, D. P. (2005). Vygotskian concepts for teacher education. Lifelong Learning: Proceedings of the 4th Annual JALT Pan-SIG Conference. May 14-15, 2005. Tokyo, Japan: Tokyo Keizai University.

Wolvin, A. \& Coakley, C. (1988). Listening, Brown, Dubuque, lowa, USA.

Wood, D., Bruner, J., \& Ross, G. (1976). The role of tutoring in problem solving. Journal of Child Psychology and Child Psychiatry, 17, 89-100. 